\title{
Using Next-Generation Sequencing to Identify a Mutation in Human MCSU that is Responsible for Type II Xanthinuria
}

\author{
Yunan Zhou Xueguang Zhang Rui Ding Zuoxiang Li Quan Hong Yan Wang \\ Wei Zheng Xiaodong Geng Meng Fan Guangyan Cai Xiangmei Chen Di Wu \\ Department of Nephrology, Chinese PLA General Hospital, Chinese PLA Institute of Nephrology, State \\ Key Laboratory of Kidney Diseases, National Clinical Research Center for Kidney Diseases Beijing, China
}

\section{Key Words}

Hypouricemia - Xanthinuria - Human molybdenum cofactor sulfurase (MCSU) - Xanthine dehydrogenase $(\mathrm{XDH})$ and Xanthine oxidase $(\mathrm{XOD})$

\begin{abstract}
Background: Hypouricemia is caused by various diseases and disorders, such as hepatic failure, Fanconi renotubular syndrome, nutritional deficiencies and genetic defects. Genetic defects of the molybdoflavoprotein enzymes induce hypouricemia and xanthinuria. Here, we identified a patient whose plasma and urine uric acid levels were both extremely low and aimed to identify the pathogenic gene and verify its mechanism. Methods: Using nextgeneration sequencing (NGS), we detected a mutation in the human molybdenum cofactor sulfurase (MCSU) gene that may cause hypouricemia. We cultured L02 cells, knocked down MCSU with RNAi, and then detected the uric acid and MCSU concentrations, xanthine oxidase (XOD) and xanthine dehydrogenase (XDH) activity levels, and xanthine/hypoxanthine concentrations in cell lysates and culture supernatants. Results: The NGS results showed that the patient had a mutation in the human MCSU gene. The in vitro study showed that RNAi of MCSU caused the uric acid, human MCSU concentrations, the XOD and XDH activity levels among cellular proteins and culture supernatants to be extremely low relative to those of the control. However, the xanthine/hypoxanthine concentrations were much higher than those of the control. Conclusions: We strongly confirmed the pathogenicity of the human MCSU gene.
\end{abstract}




\section{Cellular Physiology Cell Physiol Biochem 2015;35:2412-2421

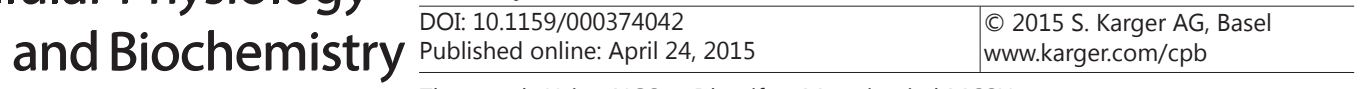 Zhou et al.: Using NGS to Identify a Mutation in hMCSU}

\section{Introduction}

Hypouricemia occurs when uric acid concentrations in blood serum are less than or equal to $2.0 \mathrm{mg} / \mathrm{dl}$ or $119 \mu \mathrm{mol} / \mathrm{l}[1,2]$. Traditionally, hypouricemia has not been given the same attention as hyperuricemia because of its low incidence rate and lack of recognizable symptoms [1]. However, hypouricemia patients suffer from elevated levels of xanthine in the urine, and these conditions may lead to xanthine stones, hematuria, and occasionally chronic kidney failure [3]. Many diseases or disorders may lead to hypouricemia, including hepatic failure, Fanconi renotubular syndrome, and nutritional deficiencies [4]. Hereditary disorders of purine metabolism can also lead to hypouricemia; such disorders include molybdoflavoprotein enzyme deficiency, purine nucleoside phosphorylase deficiency and phosphoribosylpyrophosphate synthetase deficiency. Furthermore, genetic defects in the molybdoflavoprotein (Mo) enzymes include xanthine oxidoreductase deficiency (xanthinuria type I), molybdenum cofactor sulfurase deficiency (xanthinuria type II) and molybdenum cofactor deficiency [5]. The 5 Mo-enzymes can be subdivided into 2 families, namely the SO (sulfite oxidase) and XOR (xanthine oxidoreductase) families. Nitrate reductase (which is not present in humans), SO itself, and the mitochondrial amidoxime-reducing component (mARC) are members of the SO family. XOR and aldehyde oxidase (AOX) belong to the XOR family [6, 7]. The maturation of the SO family enzymes strictly requires the presence of a molybdenum cofactor (Moco), while the XOR family enzymes require the human molybdenum cofactor sulfurase (MCSU) [8]. Type II xanthinuria is characterized by the simultaneous loss of 2 Moenzymes in the AOX family, namely XOR and AOX [9]. This enzyme loss is due to a mutation in the human MCSU gene [10]. The mutation is very rare; only 4 cases have been reported, and no in vitro studies on the mechanisms of the pathogenic gene have been performed [11-14]. Recently, we used next-generation sequencing to identify the mutation in a hypouricemia patient with type II xanthinuria and found a heterozygous nonsense mutation in the human MCSU gene. Moreover, we verified the function of the pathogenic gene in vivo and in vitro.

\section{Materials and Methods}

Patient

A 42-year-old male patient was admitted to our department because of hypouricemia and mild albuminuria. His physical examination showed a fatty liver, multiple liver cysts and hypertension. Laboratory examinations revealed that his serum gamma-glutamyl transpeptidase (GGT) was high (71.3 $\mathrm{U} / \mathrm{L})$, his plasma uric acid level was extremely low $(2.1 \mu \mathrm{mol} / \mathrm{L})$, and his 24 -h urine uric acid was low (0.0$0.02 \mathrm{mmol} / \mathrm{L}$ ). The patient reported no history of urinary calculi or myositis and reported no family history of hypouricemia. The venous blood and urine of the patient were obtained following a morning fast. The serum and urine supernatants were used for the experiments.

\section{Control group}

The control group consisted of 10 healthy patients who came to our hospital for physical examinations and excluded patients with renal dysfunction, hypouricemia, albuminuria and hematuria. The average age of the patients in the control group was approximately 40 years, and it included 6 men and 4 women. The venous blood and urine from all patients were obtained following morning fasts. The serum and urine supernatants were used for the experiments.

Next-generation Sequencing

Whole-exome sequencing was performed by Beijing GGT Co using an Ion Torrent sequencing system. High-quality genomic DNA was obtained by super-multiple PCR amplification technology, and 294,000 primer pairs from 12 super-multiple PCR primer pools covering approximately $97 \%$ of the consensus coding sequences were used to amplify the genomic DNA. Next, DNA coding exons were sequenced using the Ion Proton ${ }^{\mathrm{TM}}$ System (Life Technologies) with a semiconductor sequencer as the core technology. This technology has recently been applied to genetic research in various fields, including oncology [15-18], hematology [19], and intellectual disability [20]. 


\section{Cellular Physiology Cell Physiol Biochem 2015;35:2412-2421 \begin{tabular}{ll|l} 
and Biochemistry & $\begin{array}{l}\text { DOI: 10.1159/000374042 } \\
\text { Published online: April 24, } 2015\end{array}$ & $\begin{array}{l}\text { O } 2015 \mathrm{~S} . \text { Karger AG, Basel } \\
\text { www.karger.com/cpb }\end{array}$ \\
\cline { 2 - 3 }
\end{tabular} Zhou et al.: Using NGS to Identify a Mutation in hMCSU}

Materials

A human molybdenum cofactor sulfurase (MCSU) ELISA Kit (CSB-EL014702HU) was purchased from CUSABIO. A xanthine/hypoxanthine assay kit (ab155900) was purchased from Abcam. An XOD activity colorimetric assay kit (catalog \#K710-100) was purchased from BioVision. Xanthine (x0626) was purchased from Sigma. NAD ${ }^{+}$(sc-208084) was purchased from Santa Cruz Biotechnology.

Cell line

The human immortal hepatic cell line L02 was obtained from the Type Culture Collection of the Chinese Academy of Sciences (Shanghai, China). Cultures were maintained in Dulbecco's modified Eagle's medium (DMEM) (Gibco) supplemented with penicillin $(100 \mathrm{U} / \mathrm{ml})$, streptomycin $(10 \mu \mathrm{g} / \mathrm{ml})$, and $10 \%$ fetal bovine serum (Gibco) at $37^{\circ} \mathrm{C}$ in a humidified incubator with $5 \% \mathrm{CO}_{2}$ in air, and they were split 1:3 at confluence.

\section{Human MCSU Concentration Test}

Human MCSU concentrations were determined by ELISA (CUSABIO). The assay employed a quantitative sandwich enzyme immunoassay technique. Briefly, an antibody specific for human MCSU was pre-coated onto a microplate. Standards and samples were pipetted into the microplate wells, and any human MCSU present was bound by the immobilized antibodies. After washing away unbound substances, a biotin-conjugated antibody specific for human MCSU was added. After a second wash, avidin-conjugated horseradish peroxidase (HRP) was added. Following another wash to remove unbound avidin enzyme reagents, a substrate solution was added, and a color change indicated the amount of human MCSU that had bound. Finally, the color change reaction was stopped, and the optical density of each well was detected within 5 minutes by using a microplate reader at $450 \mathrm{~nm}$.

\section{Xanthine/hypoxanthine Concentration Test}

The concentration of xanthine/hypoxanthine was determined by using a xanthine/hypoxanthine assay kit (ab 155900, Abcam). Xanthine/hypoxanthine was specifically oxidized by a xanthine enzyme mix provided in the kit to form an intermediate, which then reacted with a developer and a probe to form a product that was measured colorimetrically $(\lambda=570 \mathrm{~nm})$.

\section{Enzyme Activity Test}

The activity of XOD was determined using a colorimetric XOD activity assay kit from BioVision. In this assay, XOD oxidized xanthine to hydrogen peroxide $\left(\mathrm{H}_{2} \mathrm{O}_{2}\right)$ which reacted stoichiometrically with the OxiRED ${ }^{\mathrm{TM}}$ Probe to generate a color (at $\lambda=570 \mathrm{~nm}$ ). Because the resulting color intensity is proportional to the XOD content, the XOD activity can be accurately measured. XDH activity was determined from the following reaction: xanthine $+\mathrm{NAD}^{+}+\mathrm{H}_{2} \mathrm{O} \Leftrightarrow$ uric acid $+\mathrm{NADH}+\mathrm{H}^{+}$. We then detected the abundance of uric acid and NADH to determine the activity of XDH. The uric acid content was examined in the biochemistry department at our hospital, and the NADH content was measured colorimetrically $(\lambda=340 \mathrm{~nm})$.

\section{Cell Study}

Because purine metabolism and uric acid formation occur in the liver, we verified the in vitro mechanism of the pathogenic gene by culturing L02 cells in vitro and suppressing the expression of the human MCSU gene by using small interfering RNA (siRNA). The inhibition efficiency was measured with real-time quantitative reverse transcription polymerase chain reaction (qRT-PCR). After inhibition, proteins were extracted from the cells (the concentrations of the protein were set to unity), and the culture supernatants from the cells with the inhibited human MCSU and from the negative and normal control groups were collected. The MCSU, xanthine/hypoxanthine, and uric acid concentrations, and the activity of XDH/XOD, were determined by the same methods described above.

\section{Results}

Genetic Analyses

Data from whole-exome sequencing (WES) were matched and analyzed, and the sites of variation were verified using the SANGE method. The result of WES showed that a nonsense 


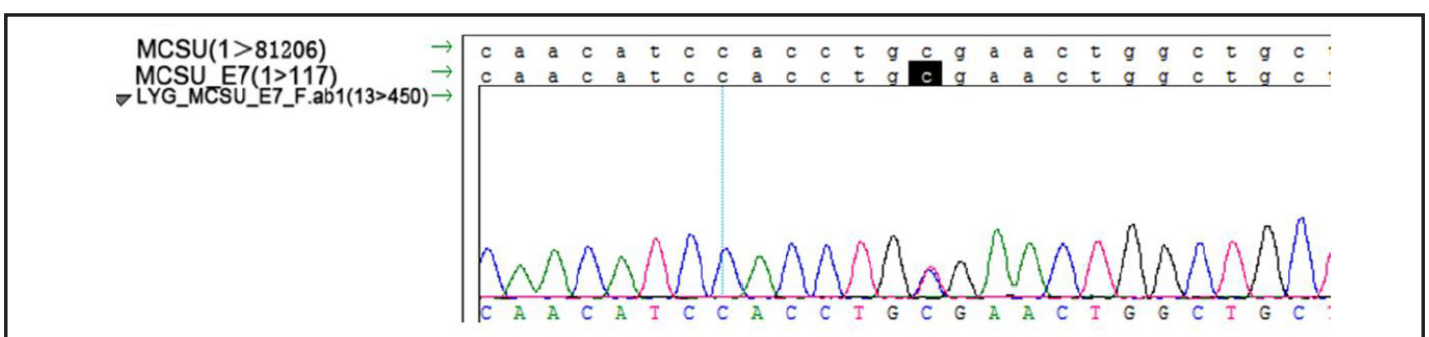

Fig. 1. Whole-exome sequencing was performed by Beijing GGT Co. The results showed a point mutation of CGA (Arg) to TGA (Ter) at codon 419 of the human MCSU gene.

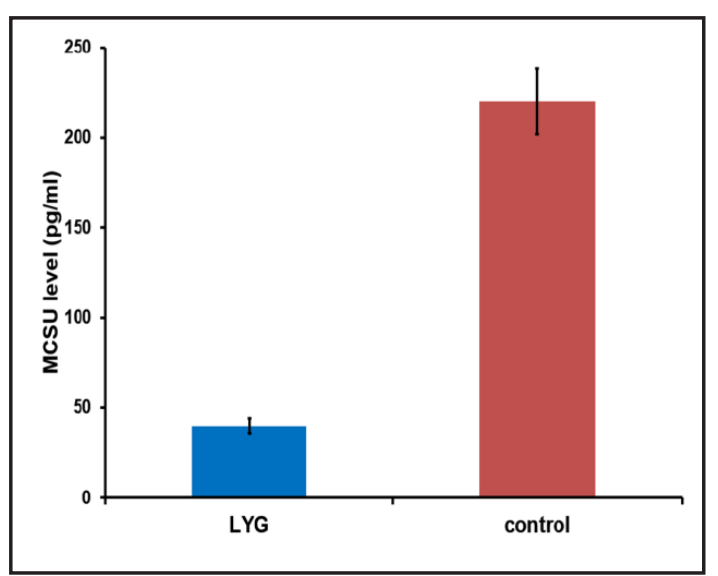

Fig. 2. The serum concentrations of human MCSU were determined by ELISA (CUSABIO). The human MCSU serum level of the test patient ( LYG )was compared to that of the control group $(n=10)$. The MCSU level of LYG was significantly lower than that of the control group $(\mathrm{p}<0.01)$.

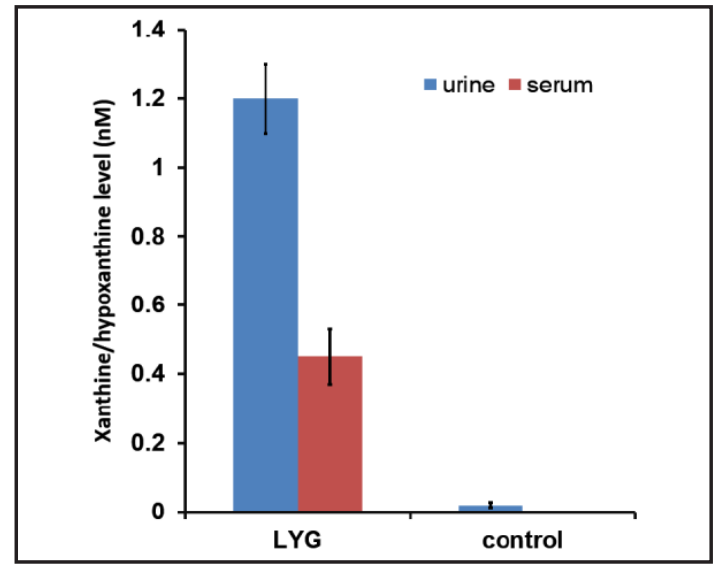

Fig. 3. The urine and serum levels of xanthine/ hypoxanthine were determined by a xanthine/hypoxanthine assay kit (ab 155900). The urine and serum levels of LYG were compared with those of the control group $(n=10)$. The urine and serum levels of LYG were both significantly higher than those of the control group $(\mathrm{p}<0.01)$.

heterozygous mutation of CGA (Arg) to TGA (Ter) was present at codon 419 in the human MCSU gene (Fig. 1).

\section{In vivo Study}

Serum concentration of human MCSU. To confirm the mutation in the MCSU gene, we first analyzed the MCSU serum concentrations of the special patient and the control group using ELISA. The MCSU expression of the patient was significantly lower than that of the control group (Fig. 2). Interestingly, the patient still had a level of human MCSU, which may be attributed to the heterozygous mutation of the MCSU gene. However, by comparing the histograms, we confirmed that the mutation in the MCSU gene resulted in human MCSU dysfunction.

Serum and urine concentrations of xanthine/hypoxanthine. To identify whether the patient was suffering from xanthinuria, we measured the serum and urine xanthine/ hypoxanthine levels. The xanthine/hypoxanthine levels of the patient were much higher than those of the control group (Fig. 3). This result suggested that the patient was suffering from xanthinuria and that it was likely associated with human MCSU mutation.

Serum XOD and XDH activity levels. We measured the activity levels of XOD and XDH, which catalyze the metabolism of hypoxanthine to xanthine and xanthine to uric acid. The XOR serum activity in the patient was markedly lower than that in the control group (Fig. 4). This finding indicated the patient suffered from severe hypouricemia due to the mutation in the human MCSU gene.

\section{KARGER}




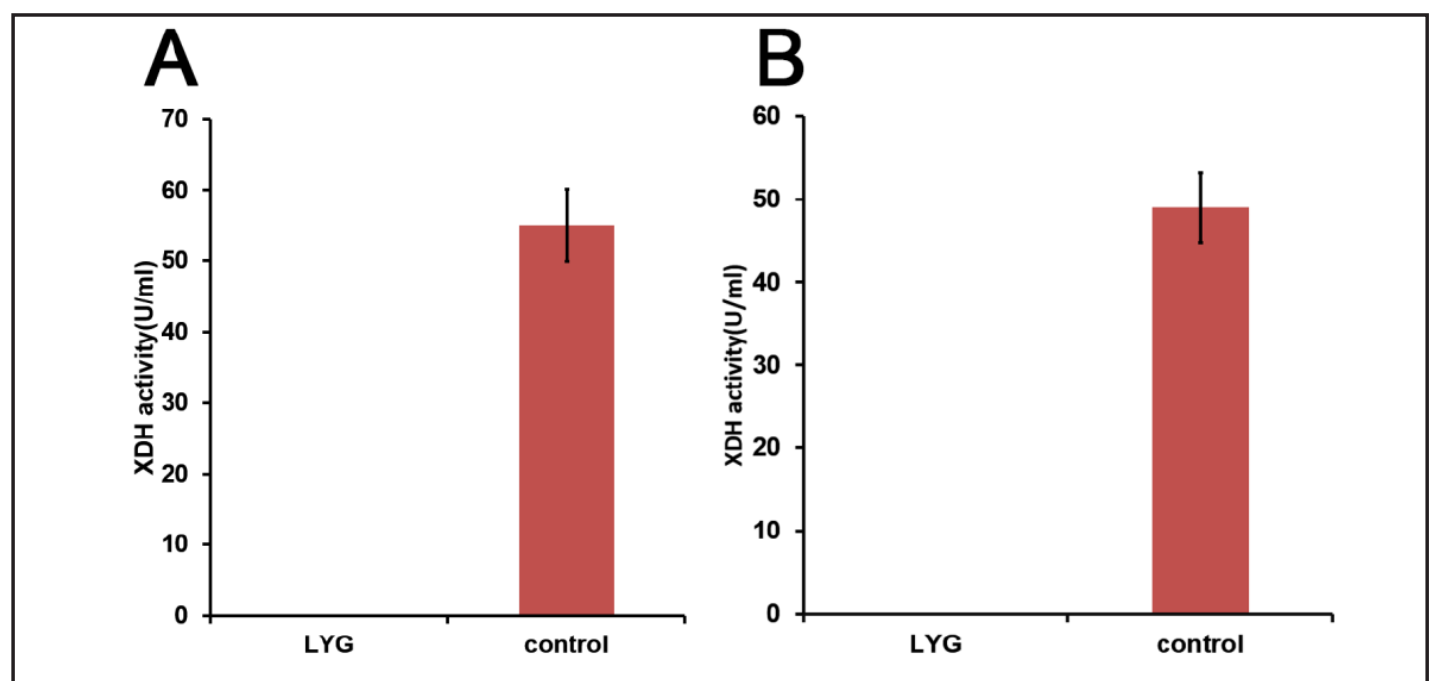

Fig. 4. Serum XOD activity was determined with a XOD activity colorimetric assay kit from BioVision, and serum XDH activity was also determined. The XOD and XDH serum activities were compared with those of the control group $(n=10)$. The XOD and XDH serum activity levels of LYG could not be detected; both were significantly lower than those of the control group $(\mathrm{p}<0.001)$.

Fig. 5. qPCR revealed the downregulation of the human MCSU gene expression in the siMCSU-treated L02 cell line compared with the normal $(n=10)$ and negative controls $(n=10)$ $(\mathrm{p}<0.01)$.

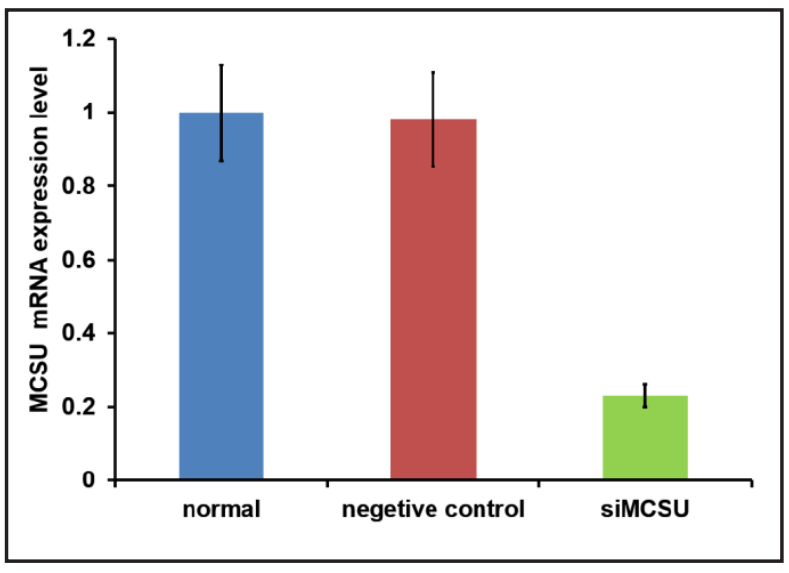

\section{In vitro Study}

Quantitative RT-PCR examination of the MCSU inhibition efficiency of the LO2 cell. To verify the function of the pathogenic gene in vitro, we suppressed the expression of the human MCSU gene in the L02 cell line with interfering RNA (RNAi). The inhibition efficiency was measured by qRT-PCR and was compared with the normal and negative controls. This experiment showed that MCSU gene expression was approximately $75 \%$ inhibited (Fig. 5). This strategy established a successful in vitro cell model of human MCSU gene mutation.

Uric acid and human MCSU concentrations among cellular proteins and in culture supernatants. To confirm the effects of the dysfunctional MCSU gene, we measured the concentrations of uric acid and human MCSU in supernatants and cell pellets using the same methods described earlier. The MCSU expressions of both the cellular proteins and culture supernatants were significantly lower than that of the control group (Fig. 6), and they suggested that the MCSU RNAi in the L02 cells achieved the same effect as the mutation in the patient.

Xanthine/hypoxanthine concentration, XOD and XDH activity among cellular proteins and in culture supernatants. Finally, we measured xanthine/hypoxanthine concentrations and XOR and XDH activities (Fig. 7). No xanthine/hypoxanthine was detected in the cell protein pellets or supernatants of the normal and control groups. However, the xanthine/ 


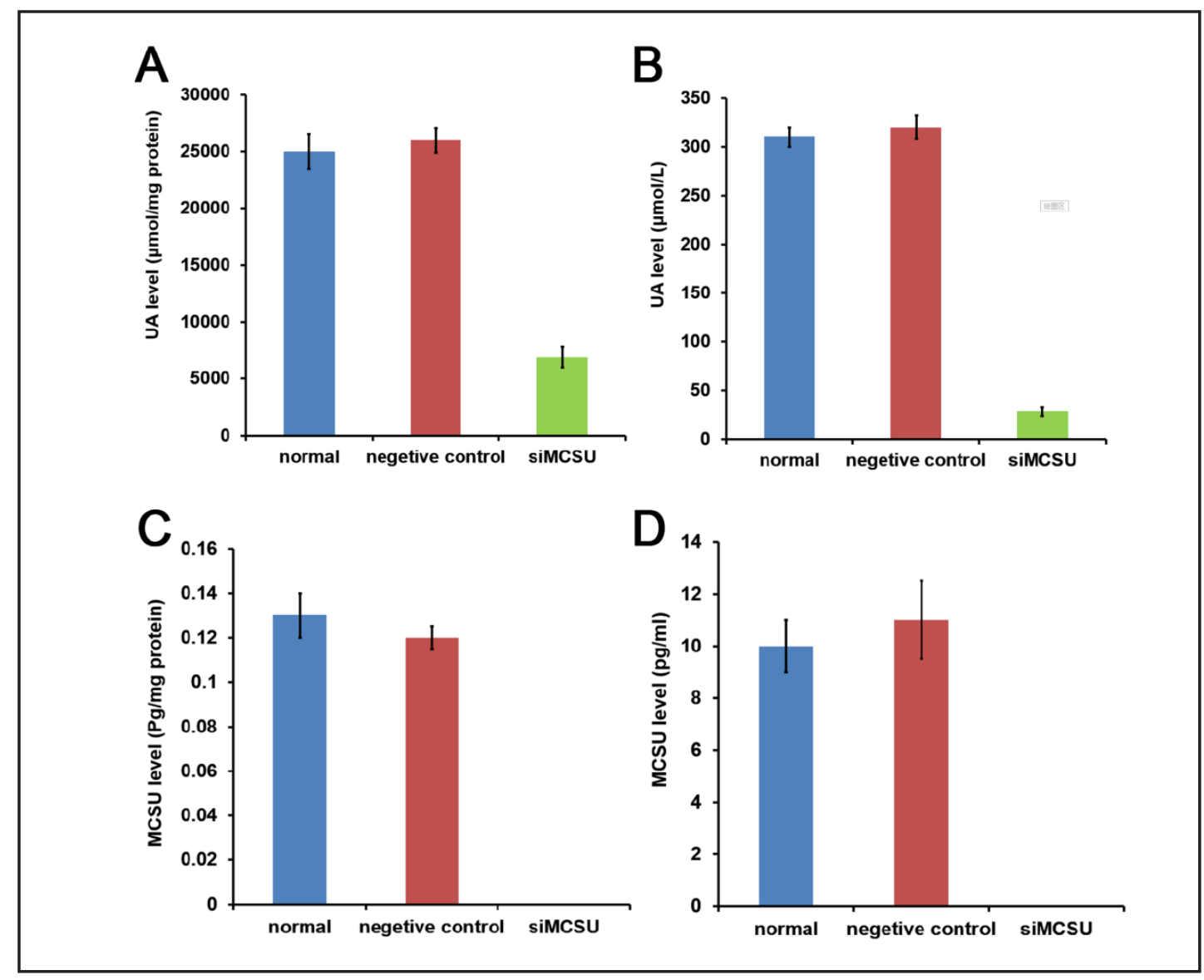

Fig. 6. The concentrations of uric acid (UA) and human MCSU were detected. A and B show the UA levels in the cellular protein and in the culture supernatant, respectively, of the siMCSU-treated L02 cell line as compared with the normal $(n=10)$ and control groups $(n=10)$. The UA levels in the cellular protein and in the culture supernatant of the siMCSU-treated L02 cell line were both significantly lower than those in the normal and control groups. C and D show the human MCSU levels in the cellular protein and in the culture supernatant, respectively, of the siMCSU-treated L02 cell line as compared with the normal $(\mathrm{n}=10)$ and control groups $(n=10)$. The human MCSU levels in the cellular protein and in the culture supernatant in the siMCSU-treated L02 cell line were both significantly lower than those in the normal and control groups.

hypoxanthine levels in both the cell protein pellets and supernatants of cells subjected to MCSU RNAi were extremely high. No XOD or XDH activities were detected in the cell protein pellets or supernatants of the cells subjected to MCSU RNAi. Thus, the effect that human MCSU gene mutation had on MCSU function and hence on hypouricemia and xanthinuria was verified using in vivo and vitro studies.

\section{Discussion}

In this study, we identified a rare monogenic mutation in a hypouricemia patient by using next-generation sequencing, and we determined that the mutation was a heterozygous nonsense mutation of CGA (Arg) to TGA (Ter) at codon 419 in the human MCSU gene (i.e., the pathogenic type II xanthinuria gene) [10]. To verify the pathogenic mechanism of this gene, we performed a series of in vivo and in vitro examinations, which suggested that the mutation of the human MCSU gene played an important role in the hypouricemia and type II xanthinuria of the patient.

\section{KARGER}


Fig. 7. The concentrations of xanthine/hypoxanthine were determined along with XOD and XDH activity. A and $B$ show the xanthine/ hypoxanthine levels in the cellular protein and in the culture supernatant, respectively, of the siMCSU-treated L02 cell line as compared with the normal $(\mathrm{n}=10)$ and control groups $(\mathrm{n}=10)$. Xanthine/hypoxanthine could not be detected in either the cellular protein or culture supernatant of the normal or control groups. However, the xanthine/hypoxanthine levels in both the cellular protein and culture supernatant of the siMCSU-treated cells were extremely high. C and $\mathrm{D}$ show the levels of XOD activity in the cellular protein and in the culture supernatant, respectively, of the siMCSU-treated L02 cell line as compared with the normal (n $=10)$ and control groups $(\mathrm{n}=10)$. No XOD activity could be detected in the cellular protein or cul-

A

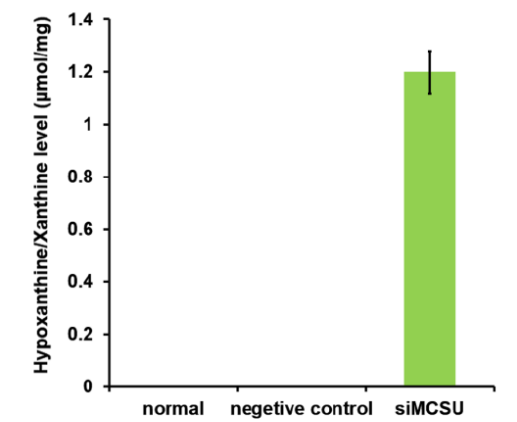

C
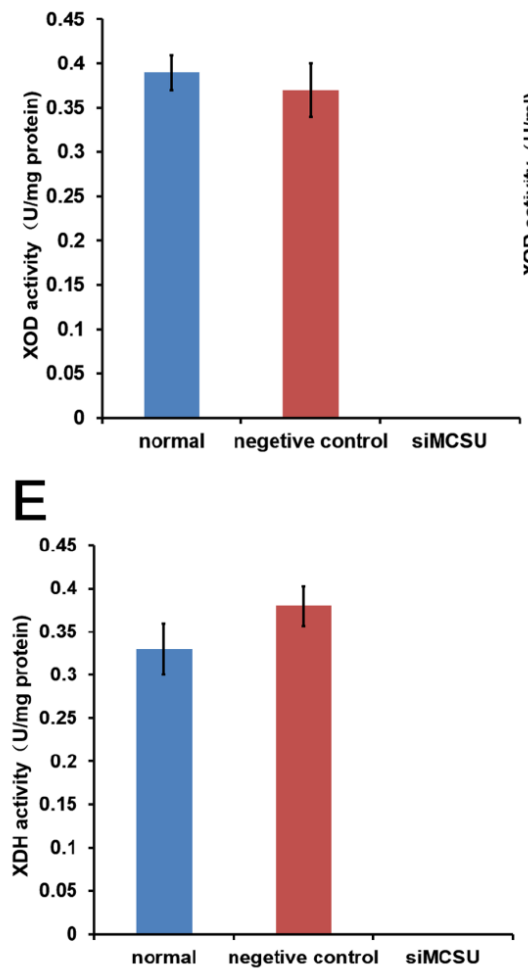
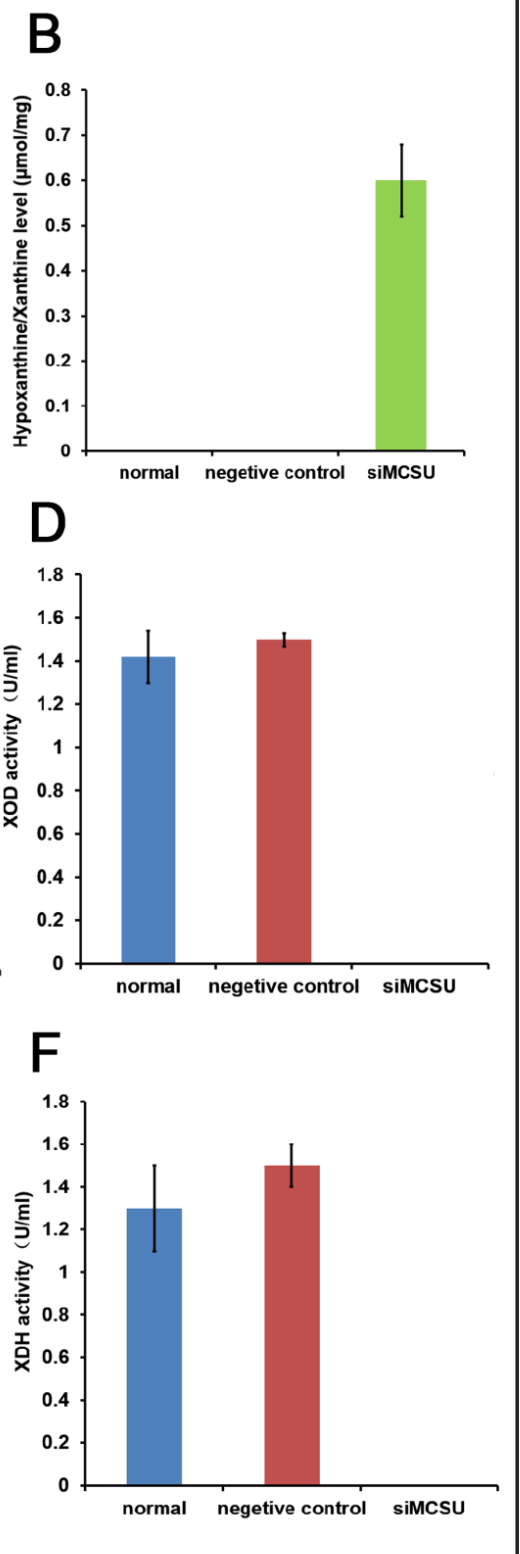
ture supernatant of the siMCSU-treated cells; the activity level was thus significantly lower than those of the normal and control groups. E and F show the XDH activity levels in the cellular protein and in the culture supernatant, respectively, of the siMCSU-treated L02 cell line as compared with the normal $(\mathrm{n}=10)$ and control groups $(\mathrm{n}=10)$. No XDH activity could be detected in the cellular protein or culture supernatant of the siMCSU-treated cells; the activity level was significantly lower than those of the normal and control groups.

Molybdenum cofactor (Moco) is a low-molecular-weight pterin derivative and can endow activity to molybdenum (Mo), which is essential for important cellular processes [21, 22]. Moco is at the catalytic center of a class of molybdoenzymes. Oxo-transfer reactions, such as the hydroxylation of substrates, are catalyzed at the molybdenum center. The human MCSU gene encodes a two-domain protein that catalyzes the sulfuration of Moco in the enzymes of the XO family and is responsible for the activation of XOR and AOX [10]. Deficiency in human MCSU results in the simultaneous loss of XOR and AOX activities [5]. $\mathrm{XDH}$ and XOD are enzymes that are involved in the metabolism of purines and pyrimidines in various organisms [23]. XDH and XOD can be interconverted in some particular cases [23]. Hereafter, we will use the term XOR (xanthine oxidoreductase) to refer to both forms of 


\section{Cellular Physiology Cell Physiol Biochem 2015;35:2412-2421 \begin{tabular}{ll|l} 
DOI: 10.1159/000374042 & $\begin{array}{l}\text { O 2015 S. Karger AG, Basel } \\
\text { www.karger.com/cpb }\end{array}$ \\
\hline
\end{tabular} \\ Zhou et al.: Using NGS to Identify a Mutation in hMCSU}

the enzyme. XOR is the enzyme that catalyzes the metabolism of hypoxanthine to xanthine and xanthine to uric acid. Therefore, inactivation of XOR results in hypouricemia and xanthinuria. Studies with similarity to the present study have been performed $[11,12,14]$. In 2001, Ichida reported 2 cases of type II xanthinuria in which the patients carried the same mutation in the MCSU gene as the patient in the present study. These patients all showed nonsense substitutions from CGA (Arg) to TGA (Ter) at codon 419 in the MCSU gene [11]. Yamamoto reported a case with a point mutation from $G$ to $C$ in exon 2 of the human MCSU gene [12]. We used next-generation sequencing instead of direct sequencing, thus yielding more comprehensive and accurate results [24]. In previous studies, the activity of XDH was measured by HPLC $[11,12]$, which was complicated and time-consuming. Here, we have developed a new method that permits simpler and more rapid measurement.

Previous studies have also reported diseases associated with type II xanthinuria. These diseases often result in hematuria or renal colic but rarely in acute renal failure or chronic complications related to urolithiasis [9]. Xanthine deposition could also cause muscle pains [14]. A case of hereditary type II xanthinuria in a child led to mental delay and autism, cortical renal cysts, osteopenia, hair and tooth defects, and a range of behavioral symptoms [13]. Approximately half of the symptoms affecting development were caused by the deposition of xanthine in the urinary tract [25]. However, the patient in our study did not show any of these symptoms, a difference that may be partly attributed to the heterozygous mutation. Another study reported a bovine type II xanthinuria that was associated with a deletion mutation at tyrosine 257 in MCSU [10].

To further verify the function of the mutation, we also performed in vitro experiments. Because purine metabolism and uric acid formation occur in the liver, we established an in vitro cell model with the L02 human hepatic cell line by using RNAi. Supernatants and cell protein pellets were collected and examined as in the in vivo experiments. The in vitro results were consistent with those in vivo. Therefore, the dysfunction of the MCSU enzyme may be responsible for hypouricemia and xanthinuria. Next-generation sequencing and comparable in vitro experiments were not performed in any of the previous studies. Studies of molybdenum cofactor deficiency (MoCD) made use of knockout mice to study the molecular basis and treatment of human MoCD [26, 27]. To confirm our hypothesis, we next intend to establish animal models, namely homozygous $\mathrm{MCSU}^{-/-}$and heterozygous $\mathrm{MCSU}^{-/+}$ mice. The MCSU gene may be selected as a novel potential treatment target for refractory hyperuricemia and gout. Patients with these diseases often require a combined therapy of drugs and pegloticase [28-30], which sometimes has serious adverse side effects that include anaphylactic reactions, skin infections, thrombocytopenia and severe cardiac issues [31]. However, the role of AOX is not clear. It may be risky to suppress AOX activity due to its role in phase I drug metabolism. Therefore, further study of AOX and the human MCSU gene is warranted.

\section{Disclosure Statement}

There is no conflict for each author.

\section{Acknowledgment}

This work is supported by the National High Technology Research and Development Program of China (2012AA02A512), Major State Basic Research Development Program (2013CB530800), The National Key Technology R\&D Program (2011BAI10B00), Chinese National Natural Sciences Foundation (No. 31170810, No. 81470949) and the Beijing NOVA Program (Z121107002512078). 


\section{Cellular Physiology Cell Physiol Biochem 2015;35:2412-2421 \begin{tabular}{l|l|l}
\hline DOI: 10.1159/000374042 & (C) 2015 S. Karger AG, Basel
\end{tabular} and Biochemistry Published online: April 24, 2015 \\ Zhou et al.: Using NGS to Identify a Mutation in hMCSU}

\section{References}

1 Esparza Martin N, Garcia Nieto V: Hypouricemia and tubular transport of uric acid. Nefrologia 2011;31:4450.

2 Sebesta I, Stiburkova B, Bartl J, Ichida K, Hosoyamada M, Taylor J, Marinaki A: Diagnostic tests for primary renal hypouricemia. Nucleosides Nucleotides Nucleic Acids 2011;30:1112-1116.

3 Sebesta I, Stiburkova B: Purine disorders with hypouricemia. Prilozi 2014;35:87-92.

4 Fujimori S: [Hypouricemia--definition and classification]. Nihon Rinsho 2003;61:S353-356.

5 Ichida K, Amaya Y, Okamoto K, Nishino T: Mutations associated with functional disorder of xanthine oxidoreductase and hereditary xanthinuria in humans. Int J Mol Sci 2012;13:15475-15495.

$6 \quad$ Hille R: The Mononuclear Molybdenum Enzymes. Chem Rev 1996;96:2757-2816.

7 Kitamura S, Sugihara K, Ohta S: Drug-metabolizing ability of molybdenum hydroxylases. Drug Metab Pharmacokinet 2006;21:83-98.

8 Klein JM, Schwarz G: Cofactor-dependent maturation of mammalian sulfite oxidase links two mitochondrial import pathways. J Cell Sci 2012;125:4876-4885.

9 Ichida K, Amaya Y, Kamatani N, Nishino T, Hosoya T, Sakai O: Identification of two mutations in human xanthine dehydrogenase gene responsible for classical type I xanthinuria. J Clin Invest 1997;99:2391-2397.

10 Watanabe T, Ihara N, Itoh T, Fujita T, Sugimoto Y: Deletion mutation in Drosophila ma-l homologous, putative molybdopterin cofactor sulfurase gene is associated with bovine xanthinuria type II. J Biol Chem 2000;275:21789-21792.

11 Ichida K, Matsumura T, Sakuma R, Hosoya T, Nishino T: Mutation of human molybdenum cofactor sulfurase gene is responsible for classical xanthinuria type II. Biochem Biophys Res Commun 2001;282:1194-1200.

12 Yamamoto T, Moriwaki Y, Takahashi S, Tsutsumi Z, Tuneyoshi K, Matsui K, Cheng J, Hada T: Identification of a new point mutation in the human molybdenum cofactor sulferase gene that is responsible for xanthinuria type II. Metabolism 2003;52:1501-1504.

13 Zannolli R, Micheli V, Mazzei MA, Sacco P, Piomboni P, Bruni E, Miracco C, de Santi MM, Terrosi Vagnoli P, Volterrani L, Pellegrini L, Livi W, Lucani B, Gonnelli S, Burlina AB, Jacomelli G, Macucci F, Pucci L, Fimiani M, Swift JA, Zappella M, Morgese G: Hereditary xanthinuria type II associated with mental delay, autism, cortical renal cysts, nephrocalcinosis, osteopenia, and hair and teeth defects. J Med Genet 2003;40:e121.

14 Peretz H, Naamati MS, Levartovsky D, Lagziel A, Shani E, Horn I, Shalev H, Landau D: Identification and characterization of the first mutation (Arg776Cys) in the C-terminal domain of the Human Molybdenum Cofactor Sulfurase (HMCS) associated with type II classical xanthinuria. Mol Genet Metab 2007;91:23-29.

15 Schleiermacher G, Javanmardi N, Bernard V, Leroy Q, Cappo J, Rio Frio T, Pierron G, Lapouble E, Combaret V, Speleman F, de Wilde B, Djos A, Ora I, Hedborg F, Trager C, Holmqvist BM, Abrahamsson J, Peuchmaur M, Michon J, Janoueix-Lerosey I, Kogner P, Delattre O, Martinsson T: Emergence of new ALK mutations at relapse of neuroblastoma. J Clin Oncol 2014;32:2727-2734.

16 Wang L, Yamaguchi S, Burstein MD, Terashima K, Chang K, Ng HK, Nakamura H, He Z, Doddapaneni H, Lewis L, Wang M, Suzuki T, Nishikawa R, Natsume A, Terasaka S, Dauser R, Whitehead W, Adekunle A, Sun J, Qiao Y, Marth G, Muzny DM, Gibbs RA, Leal SM, Wheeler DA, Lau CC: Novel somatic and germline mutations in intracranial germ cell tumours. Nature 2014;511:241-245.

17 Wang Y, McKay JD, Rafnar T, Wang Z, Timofeeva MN, Broderick P, Zong X, Laplana M, Wei Y, Han Y, Lloyd A, Delahaye-Sourdeix M, Chubb D, Gaborieau V, Wheeler W, Chatterjee N, Thorleifsson G, Sulem P,Liu G, Kaaks R, Henrion M, Kinnersley B, Vallee M, LeCalvez-Kelm F, Stevens VL, Gapstur SM, Chen WV, Zaridze D, Szeszenia-Dabrowska N, Lissowska J, Rudnai P, Fabianova E, Mates D, Bencko V, Foretova L, Janout V, Krokan HE, Gabrielsen ME, Skorpen F, Vatten L, Njolstad I, Chen C, Goodman G, Benhamou S, Vooder T, Valk K, Nelis M, Metspalu A, Lener M, Lubinski J, Johansson M, Vineis P, Agudo A, Clavel-Chapelon F, Bueno-de-Mesquita HB, Trichopoulos D, Khaw KT, Johansson M, Weiderpass E, Tjonneland A, Riboli E, Lathrop M, Scelo G, Albanes D, Caporaso NE, Ye Y, Gu J, Wu X, Spitz MR, Dienemann H, Rosenberger A, Su L, Matakidou A, Eisen T, Stefansson K, Risch A, Chanock SJ, Christiani DC, Hung RJ, Brennan P, Landi MT, Houlston RS, Amos CI: Rare variants of large effect in BRCA2 and CHEK2 affect risk of lung cancer. Nat Genet 2014;46:736-741.

18 Cristofoletti C, Picchio MC, Lazzeri C, Tocco V, Pagani E, Bresin A, Mancini B, Passarelli F, Facchiano A, Scala E, Lombardo GA, Cantonetti M, Caprini E, Russo G, Narducci MG: Comprehensive analysis of PTEN status in Sezary syndrome. Blood 2013;122:3511-3520. 


\section{Cellular Physiology Cell Physiol Biochem 2015;35:2412-2421 \begin{tabular}{ll|l} 
and Biochemistry $10.1159 / 000374042$ & $\begin{array}{l}\text { D 2015 S. Karger AG, Basel } \\
\text { Published online: April 24, 2015 }\end{array}$ & \begin{tabular}{l} 
www.karger.com/cpb \\
\cline { 2 - 3 }
\end{tabular} \\
\cline { 1 - 2 }
\end{tabular} \\ Zhou et al.: Using NGS to Identify a Mutation in hMCSU}

19 Gilissen C, Hehir-Kwa JY, Thung DT, van de Vorst M, van Bon BW, Willemsen MH, Kwint M, Janssen IM, Hoischen A, Schenck A, Leach R, Klein R, Tearle R, Bo T, Pfundt R, Yntema HG, de Vries BB, Kleefstra T, Brunner HG, Vissers LE, Veltman JA: Genome sequencing identifies major causes of severe intellectual disability. Nature 2014;511:344-347.

20 Probst C, Ringel P, Boysen V, Wirsing L, Alexander MM, Mendel RR, Kruse T: Genetic characterization of the Neurospora crassa molybdenum cofactor biosynthesis. Fungal Genet Biol 2014;66:69-78.

21 Reschke S, Sigfridsson KG, Kaufmann P, Leidel N, Horn S, Gast K, Schulzke C, Haumann M, Leimkuhler S: Identification of a bis-molybdopterin intermediate in molybdenum cofactor biosynthesis in Escherichia coli. J Biol Chem 2013;288:29736-29745.

22 Hille R, Nishino T: Flavoprotein structure and mechanism. 4. Xanthine oxidase and xanthine dehydrogenase. Faseb j 1995;9:995-1003.

23 Mardis ER: Next-generation DNA sequencing methods. Annu Rev Genomics Hum Genet 2008;9:387-402.

24 Schwarz G, Belaidi AA: Molybdenum in human health and disease. Met Ions Life Sci 2013;13:415-450.

25 Lee HJ, Adham IM, Schwarz G, Kneussel M, Sass JO, Engel W, Reiss J: Molybdenum cofactor-deficient mice resemble the phenotype of human patients. Hum Mol Genet 2002;11:3309-3317.

26 Feng G, Tintrup H, Kirsch J, Nichol MC, Kuhse J, Betz H, Sanes JR: Dual requirement for gephyrin in glycine receptor clustering and molybdoenzyme activity. Science 1998;282:1321-1324.

27 Maekawa M, Tomida H, Aoki T, Hishida M, Morinaga T, Tamai H: Successful treatment of refractory gout using combined therapy consisting of febuxostat and allopurinol in a patient with chronic renal failure. Intern Med 2014;53:609-612.

28 Lipsky PE, Calabrese LH, Kavanaugh A, Sundy JS, Wright D, Wolfson M, Becker MA: Pegloticase immunogenicity: the relationship between efficacy and antibody development in patients treated for refractory chronic gout. Arthritis Res Ther 2014;16:R60.

29 Hershfield MS, Ganson NJ, Kelly SJ, Scarlett EL, Jaggers DA, Sundy JS: Induced and pre-existing antipolyethylene glycol antibody in a trial of every 3-week dosing of pegloticase for refractory gout, including in organ transplant recipients. Arthritis Res Ther 2014;16:R63.

30 Pegloticase. An excessively dangerous and inadequately evaluated hypouricaemic drug. Prescrire Int 2014;23:173-176. 